\title{
Perbandingan Dosis Serap Berkas Foton 16 MV Pada Berbagai Jenis Phantom menggunakan Metode Monte Carlo - EGSnrc
}

\author{
Ridwan Ramdani $^{1}{ }^{*}$, Freddy Haryanto ${ }^{2}$ \\ ${ }^{1}$ Jurusan Fisika, Fakultas Sains dan Teknologi UIN Sunan Gunung Djati \\ Jl. A.H. Nasution No.105 Cibiru Bandung 40614 \\ ${ }^{2}$ Departemen Fisika, FMIPA Institut Teknologi Bandung \\ Jl.Ganesha No.10 Bandung 40132 \\ *E-mail: ridwan@fst.uinsgd.ac.id
}

Telp/hp: 085795903881

\begin{abstract}
ABSTRAK
Telah dilakukan penelitian tentang perbandingan dosis serap berkas foton $16 \mathrm{MV}$ pada berbagai jenis material phantom dengan menggunakan simulasi Monte Carlo-EGSnrc. Tujuan dari penelitian ini adalah membandingkan dosis serap pada berbagai jenis medium phantom yaitu jaringan lunak, paru-paru, tulang dan pmma serta pada medium non homogen. Penelitian ini dilakukan dengan menggunakan simulasi Monte Carlo BEAMnrc dan DOSXYZnrc yang merupakan pengembangan dari EGSnrc. BEAMnrc digunakan untuk memodelkan dan mensimulasikan kepala linac dengan SSD $100 \mathrm{~cm}$ dan Field size $10 \times 10 \mathrm{~cm}^{2}$. DOSXYZnrc digunakan untuk memodelkan phantom 40x40x40 $\mathrm{cm}^{3}$ dan mensimulasikan dosis serap pada phantom tersebut. Berdasarkan penelitian yang telah dilakukan didapatkan hasil bahwa kedalaman pada dosis maksimum masing-masing adalah $2.7 \mathrm{~cm}$ untuk jaringan lunak, $9 \mathrm{~cm}$ untuk paruparu, $1.5 \mathrm{~cm}$ untuk tulang dan $2,5 \mathrm{~cm}$ untuk pmma. Untuk medium non homogen dibuat dengan menyisipkan masing-masing paru-paru dan tulang setebal $10 \mathrm{~cm}$ di phantom air pada kedalaman $15 \mathrm{~cm}$. Penyisipan tersebut
\end{abstract}


menyebabkan perubahan dosis serap untuk seluruh daerah phantom. Penambahan paru-paru setebal $10 \mathrm{~cm}$ menghasilkan rentang faktor koreksi 0,97 - 1,19, sedangkan penambahan tulang setebal $10 \mathrm{~cm}$ menghasilkan rentang faktor koreksi 0,82-1,03.

Kata Kunci: Monte Carlo; BEAMnrc; DOSXYZnrc; Percentage Depth Dose (PDD)

\begin{abstract}
Research on comparing the absorbed dose $16 \mathrm{MV}$ photon beam in the phantom has been done using a Monte Carlo simulation-EGSnrc. The purpose of this study was to compare the absorbed dose in various types of medium phantom: soft tissue, lungs, bones and pmma, also in inhomogenous phantom. This research was conducted using Monte Carlo simulation BEAMnrc and DOSXYZnrc which is the development of EGSnrc. BEAMnrc used to model and simulate the linac head with a SSD $100 \mathrm{~cm}$ and Field size 10x10 $\mathrm{cm}^{2}$. DOSXYZnrc used to design the phantom with the size of $40 \times 40 \times 40 \mathrm{~cm}^{3}$ and simulate the absorbed dose in the phantom. Based on research carried out showed that the maximum depth at each dose was $2.7 \mathrm{~cm}$ for soft tissue, $9 \mathrm{~cm}$ for lung, $1.5 \mathrm{~cm}$ for bone and $2.5 \mathrm{~cm}$ for the pmma. For nonhomogeneous medium is made by inserting each of the lung and bone as thick as 10 $\mathrm{cm}$ in the water phantom at a depth of $15 \mathrm{~cm}$. The insertion causes changes in absorbed dose to the whole area phantom. The addition of the lungs to $10 \mathrm{~cm}$ generating a correction factor ranges from 0.97 to 1.19 , while the addition of $10 \mathrm{~cm}$ thick bone produces a correction factor ranges from 0.82 to 1.03 .

Keywords: Monte Carlo; BEAMnrc; DOSXYZnrc, Percentage Depth Dose (PDD)
\end{abstract}




\section{Pendahuluan}

Pada tahun 1895 Wilhelm Conrad Roentgen menemukan Sinar-X dan tahun 1898 Currie juga menemukan Radium, penemuan tersebut menjadi awal penggunaan radiasi dalam bidang kesehatan khususnya bidang radioterapi, hal ini terbukti beberapa tahun kemudian yaitu pada tahun 1899 adanya laporan pertama tentang penyembuhan penyakit kanker dengan radiasi [1]. Dalam dunia medis terdapat tiga modalitas yang dapat digunakan untuk menangani penyakit kanker yaitu operasi, kemoterapi dan radioterapi. Radioterapi adalah terapi menggunakan radiasi, sifat sel kanker yang lebih sensitif terhadap radiasi dibandingkan dengan sel sehat inilah yang mampu memberikan alasan pengobatan kanker dengan radioterapi [7]. Prinsip radioterapi adalah memberikan dosis maksimum pada daerah sel kanker dan seminimal mungkin pada daerah sel sehat. Dalam prakteknya, sebelum dilakukan treatment langsung ke pasien maka harus dilakukan proses perencanaan radiasi (treatment planning), hasil dari perencanaan ini biasanya dapat dibandingkan dengan simulasi Monte Carlo yang merupakan gold standard untuk simulasi transport paritkel. Keberadaan berbagai jenis jaringan dalam tubuh manusia menjadi perhatian khusus dalam perencanaan radiasi, karena medium yang berbeda maka dosis serapnya pun akan berbeda. Oleh karena itu, dalam penelitian ini akan dilakukan perbandingan dosis serap pada phantom yang terdiri dari berbagai jenis medium, juga bagaimana dosis serap pada phantom yang terdiri lebih dari satu medium (non homogenous phantom). Berkas radiasi yang digunakan adalah berkas foton $16 \mathrm{MV}$ dengan field size $10 \times 10 \mathrm{~cm}^{2}$ dan SSD 100 $\mathrm{cm}$.

\section{Metode Penelitian}

Secara umum, penelitian ini dilakukan dengan dua proses. Pertama, proses simulasi kepala linac menggunakan BEAMnrc, pada proses ini simulasi dilakukan untuk mendapatkan model kepala linac yang menghasilkan berkas foton $16 \mathrm{MV}$. Model kepala linac yang digunakan adalah model yang sudah ada pada sample EGSnrc. Berkas foton yang sudah dihasilkan kemudian dianalisis karakteristiknya seperti fluence, fluence energy dan spectral distribution. Kedua, proses simulasi dosis serap pada phantom, pada proses ini berkas foton yang 131 | Copyright (C) 2016, Wahana Fisika 
sudah ada digunakan sebagai sumber input. Keluaran dari proses ini berupa data dosis serap pada berbagai jenis medium phantom.

\subsection{Desain kepala linac pada BEAMnrc}

Pada BEAMnrc terdapat berbagai macam jenis Component Modules (CMs) yang dapat digunakan untuk desain dan simulasi kepala linac yang dapat menghasilkan berkas foton dengan berbagai variasi energi, pada penelitian ini linac diatur dengan field size 10

Tabel 1. Data komponen modul kepala linac

\begin{tabular}{clc}
\hline No & Komponen Modul & CM \\
\hline 1 & Target & SLABS \\
\hline 2 & Primary Collimator & CONS3R \\
\hline 3 & Flattening Filter & FLATFILT \\
\hline 4 & Ion Chamber & CHAMBER \\
\hline 5 & Mirror & MIRROR \\
\hline 6 & Secondary Collimator & JAWS \\
\hline 7 & Udara SLAB & SLABS \\
\hline & &
\end{tabular}

x $10 \mathrm{~cm}^{2}$ dan SSD $100 \mathrm{~cm}$, output dari simulasi kepala linac pada BEAMnrc adalah berupa data phase space file ( $p h s p$ ). Data ini berisi tentang informasi partikel pada scoring plane [2]. Analisis data phsp dilakukan dengan menggunkan BEAMDP, program ini merupakan software bawaan dari BEAMnrc. Adapun data komponen modul yang digunakan untuk desain kepala linac adalah sebagai berikut:

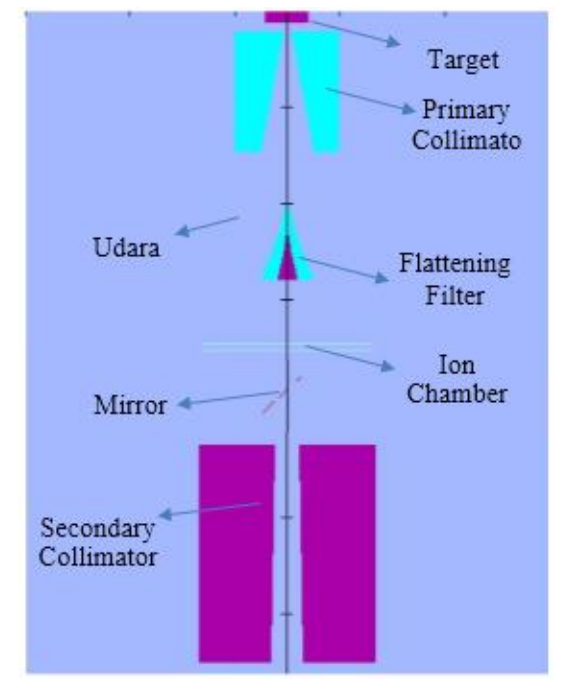

Gambar 1. Preview desain kepala linac menggunakan BEAMnrc

\subsection{Desain Phantom pada DOSXYZnrc}

DOSXYZnrc digunakan untuk melakukan desain dan simulasi dosis serap pada berbagai jenis medium phantom dengan ukuran $40 \times 40 \times 40 \mathrm{~cm}^{3}$, pada penelitian ini dosis serap yang dilihat adalah dosis serap yang berubah terhadap kedalaman atau percentage depth dose (PDD) saja, sehingga pada arah sumbu $\mathrm{Z}$ phantom dibuat volume element (voxel) yang lebih kecil dengan mengatur koordinat $(0,0)$ pada sumbu $\quad(\mathrm{X}, \mathrm{Y})$. Output dari simuasli 
DOSXYZnrc adalah berupa data .3ddose yang merupakan data distribusi dosis tiga dimensi, analisis data .3ddose dilakukan dengan menggunakan program statdose dan dosxyz_show, masing-masing dapat digunakan untuk melihat distribusi dosis satu dimensi seperti PDD dan distribusi dosis dua dan tiga dimensi (distribusi dosis $\mathrm{X}-\mathrm{Y})$. Desain phantom yang digunakan dalam penelitian ini adalah sebagai berikut:

Tabel 2. Jumlah dan ukuran voxel pada phantom

\begin{tabular}{cccc}
\hline Sumbu & Jumlah Voxel & \multicolumn{2}{c}{ Ukuran Voxel $(\mathrm{cm})$} \\
\hline \multirow{2}{*}{$\mathrm{X}$} & 3 & Voxel ke-1 & 18,5 \\
& & Voxel ke-2 & 3 \\
& & Voxel ke-3 & 18,5 \\
\hline \multirow{3}{*}{$\mathrm{Y}$} & \multirow{3}{*}{3} & Voxel ke-1 & 18,5 \\
& & Voxel ke-2 & 3 \\
& & Voxel ke-3 & 18,5 \\
\hline \multirow{2}{*}{$\mathrm{Z}$} & \multirow{3}{*}{36} & Group ke-1 (2 Voxel) & 0,4 \\
& & Group ke-1 (16 Voxel) & 0,2 \\
& & Group ke-1 (18 Voxel) & 2
\end{tabular}

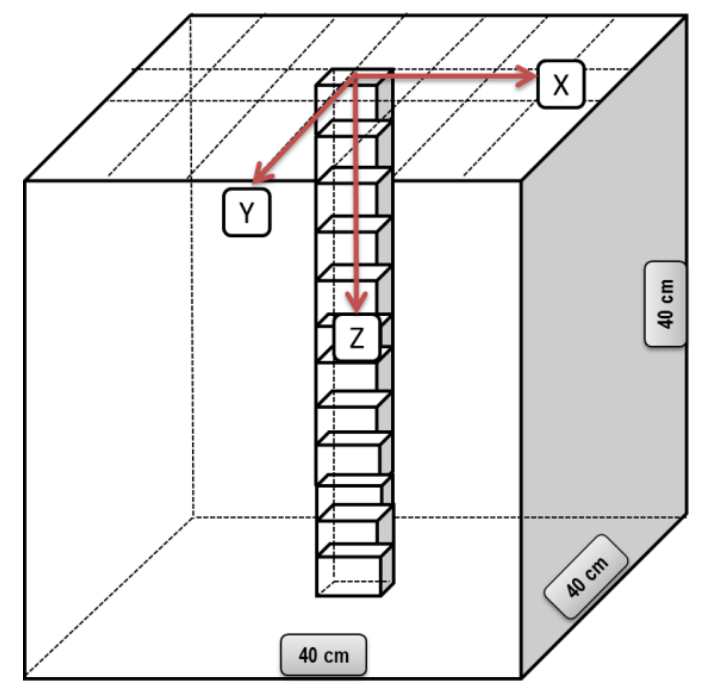

Gambar 2. Desain phantom PDD menggunakan DOSXYZnrc [4] 
Simulasi BEAMnrc dan DOSXYZnrc dilakukan secara parallel core computation dengan menggunakan 4 prosessor core i3. Proses ini dapat mereduksi waktu simulasi yang dibutuhkan karena satu proses simulasi dikerjakan oleh 4 prosessor secara bersamaan [3].

\section{Hasil dan Pembahasan}

Karakteristik berkas foton $16 \mathrm{MV}$ dapat dilihat dari fluence, fluence energy, spectral distribution dan mean energy. Karakterstik tersebut merupakan hal yang penting karena dapat mempengaruhi distribusi dosis pada phantom. Pada saat eksperimen, mendapatkan karakteristik berkas foton sangat sulit, ini karena keterbatasan detektor dan juga mesin pesawat linac yang sudah dipasang secara permanen [3]. Berikut ini adalah karateristik berkas foton 16 MV dengan field size $10 \times 10 \mathrm{~cm}^{2}$ dan SSD $100 \mathrm{~cm}$.

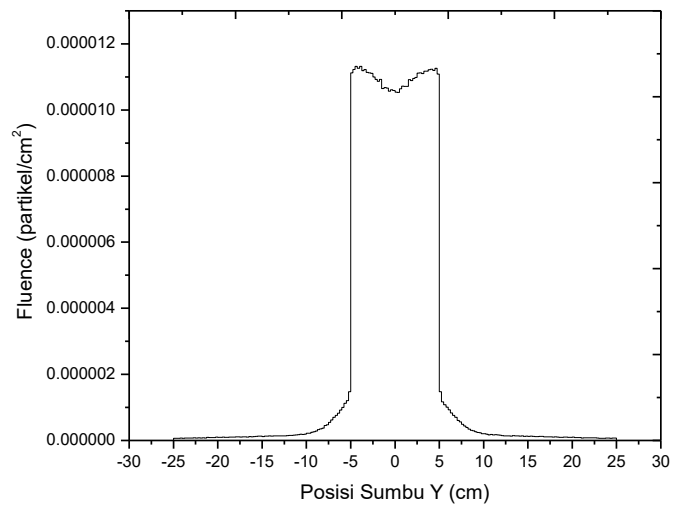

(a)

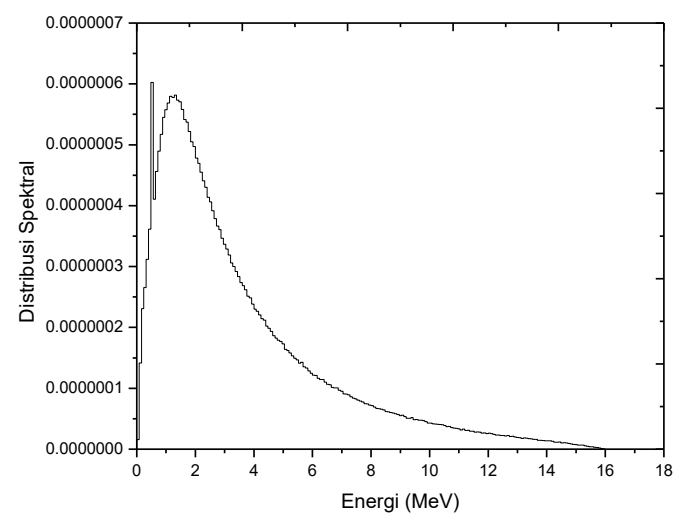

(c)

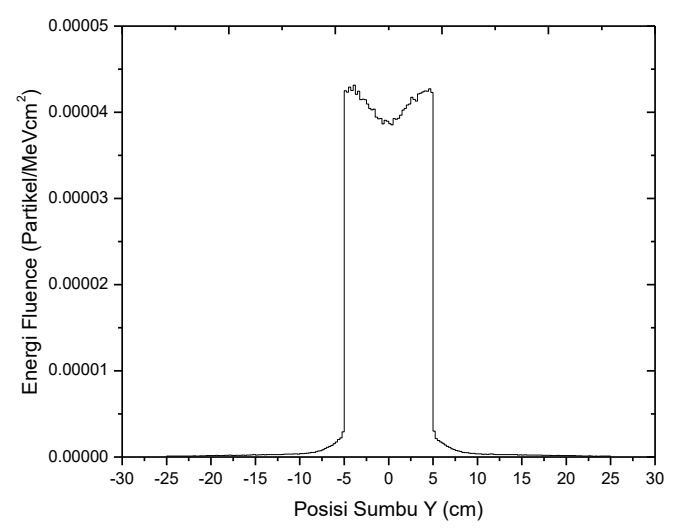

(b)

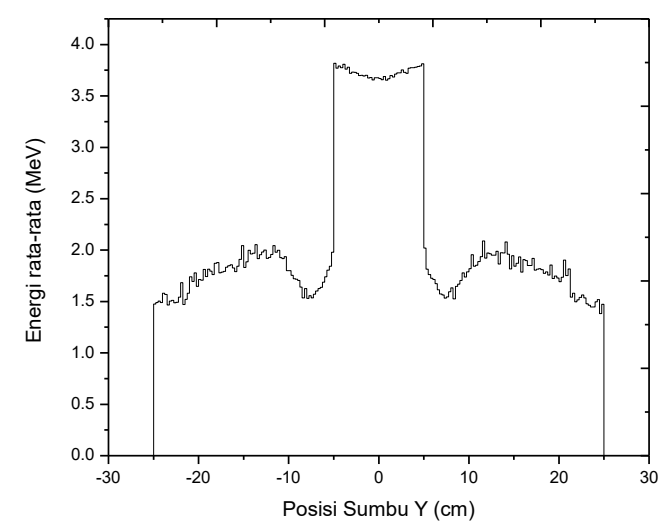

(d)

Gambar 3. Karakteristik berkas foton $16 \mathrm{MV}$ (a) fluence partikel (b) energi fluence partikel (c) distribusi spektral (d) energi rata-rata 
Dosis serap yang akan dilihat adalah dosis serap terhadap arah kedalaman phantom atau percentage depth dose (PDD). PDD ditentukan dalam bentuk dosis relatif yang menggambarkan perbadingan dosis serap pada titik tertentu terhadap dosis serap maksimum.
Medium phantom yang digunakan adalah jaringan lunak, paru-paru, tulang dan pmma serta medium non homogen yang berisi air yang disisipkan tulang dan paru-paru. Berikut ini adalah PDD pada phantom dengan berbagai jenis medium homogen.

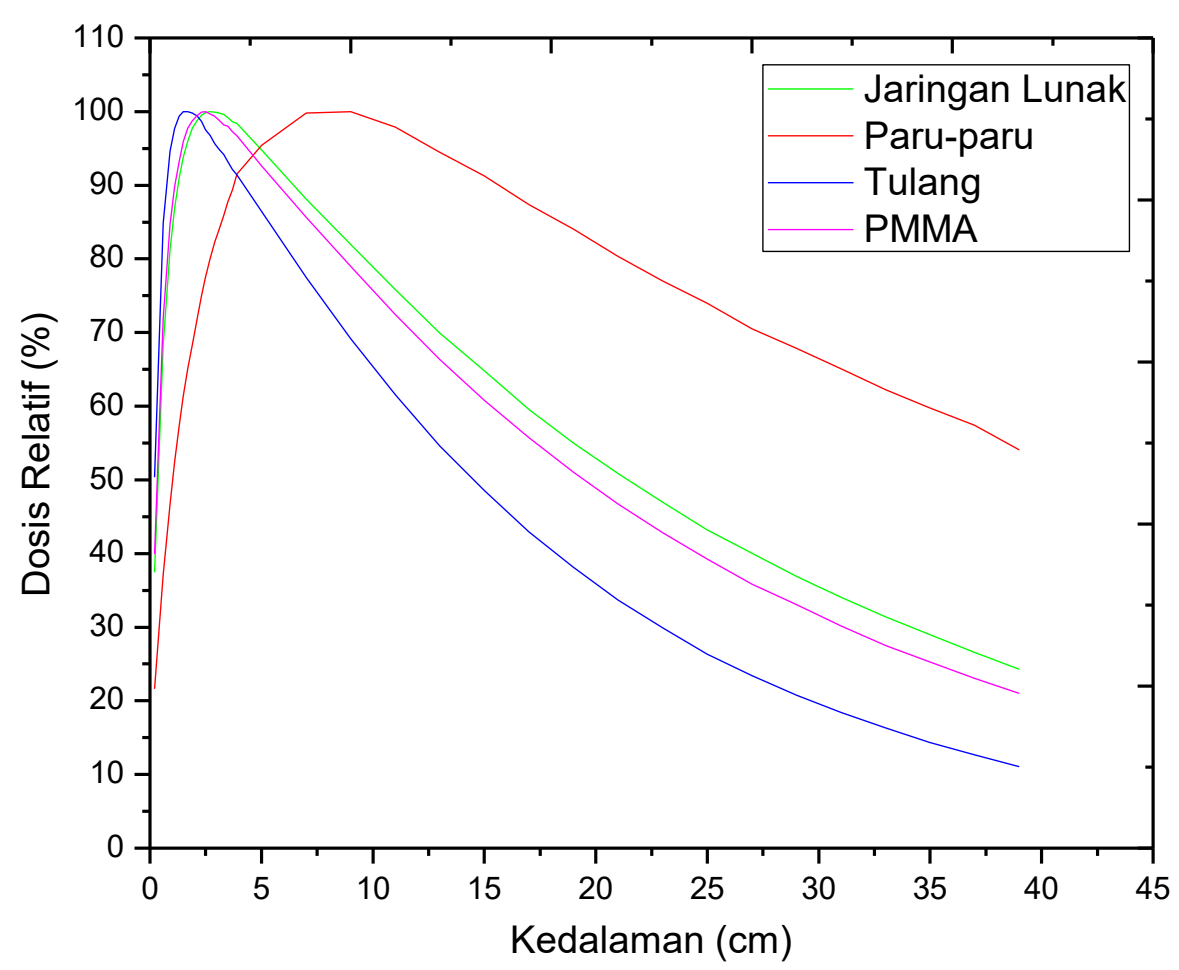

Gambar 4. PDD pada phantom homogen dengan berbagai jenis medium

Berdasarkan gambar 4 terlihat bahwa PDD untuk semua jenis medium memiliki bentuk pola yang sama, dibagian permukaan phantom maka dosis serap naik hingga mencapai kedalaman pada dosis maksimum $\left(\mathrm{D}_{\max }\right)$, kemudian dosis serap turun seiring dengan bertambahnya kedalaman phantom. Akan tetapi kedalaman pada dosis maksimum yang dihasilkan dari empat medium tersebut berbeda-beda, hasil yang didapatkan adalah jaringan lunak $2,7 \mathrm{~cm}$, paru-paru $9 \mathrm{~cm}$, tulang $1,5 \mathrm{~cm}$ dan pmma $2,5 \mathrm{~cm}$. Selama ini jaringan lunak dianggap memiliki karakteristik seperti air, sehingga dalam ekperimen sehari-hari 135 | Copyright (C) 2016, Wahana Fisika 
selalu menggunakan medium air (water phantom) [5]. Berikut ini adalah perbandingan

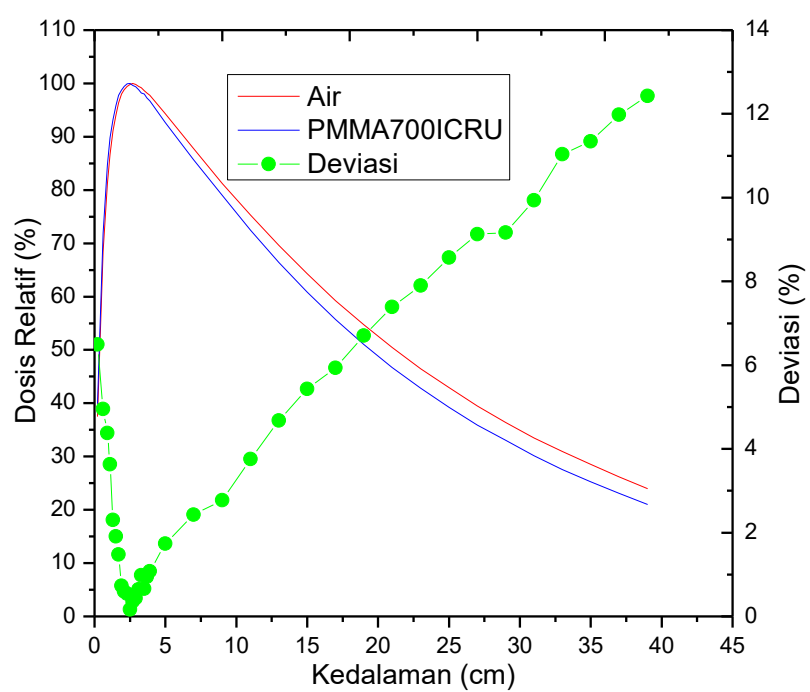

(a)
PDD antara medium air dengan jaringan lunak dan pmma.

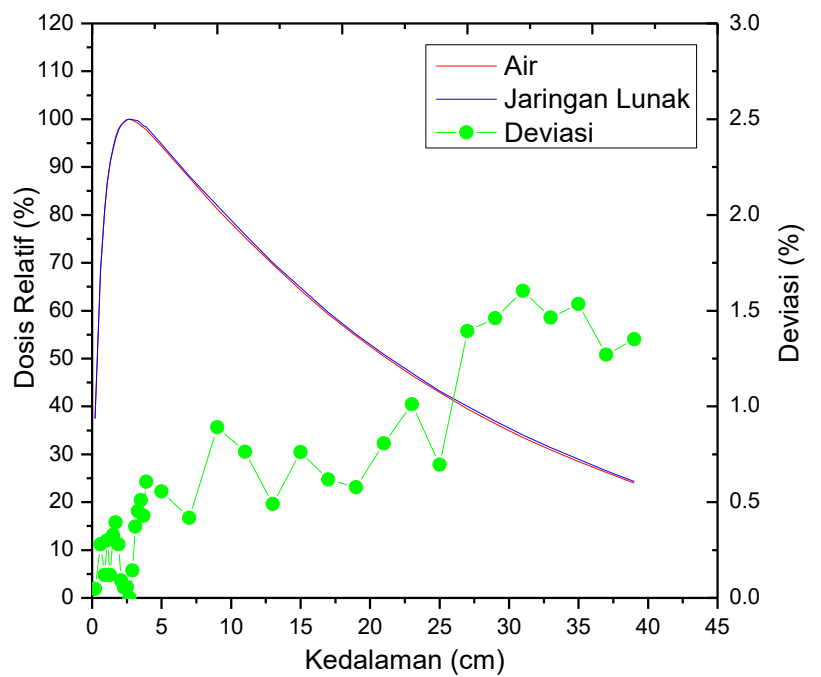

(b)

Gambar 5. Perbandingan PDD (a) air dengan pmma (b) air dengan jaringan lunak.

Kedalaman pada dosis maksium untuk medium air adalah 2,7 cm, jika dibandingkan dengan jaringan lunak dan pmma maka nilai $\mathrm{D}_{\max }$ air sama dengan jaringan lunak, sedangkan dengan pmma memiliki deviasi $7,41 \%$. Adapun deviasi dosis serap dapat dilihat pada gambar 5, berdasarkan gambar tersebut terlihat bahwa deviasi air dengan pmma lebih besar daripada air dengan jaringan lunak, rata-rata deviasi untuk air dengan pmma 4,58\% dan air dengan jaringan lunak $0,62 \%$. Sehingga dapat dikatakan bahwa jaringan lunak memiliki karakteristik yang sama dengan air. Hasil ini pun sesuai dengan penelitian sebelumnya oleh Alfian Rizani dkk yang menggunakan berkas foton $6 \mathrm{MV}$ [5].

Praktek biasanya dilakukan di rumah sakit dengan menggunakan pesawat linac, perhitungan dosis langsung diberikan kepada tubuh manusia. Bagian-bagian tubuh manusia tidak hanya terdiri dari jaringan lunak saja tetapi terdiri dari banyak jaringan misalnya tulang, paru-paru, hati, dll. Karena tubuh manusia terdiri dari berbagai jenis medium maka perhitungan dosis serap akan melibatkan faktor non homogen. Berikut ini adalah perbandingan PDD pada phantom air homogen dengan phantom air yang disisipkan 
tulang dan paru-paru setebal $10 \mathrm{~cm}$ yang homogen.

berada pada kedalaman $15 \mathrm{~cm}$ di phantom non

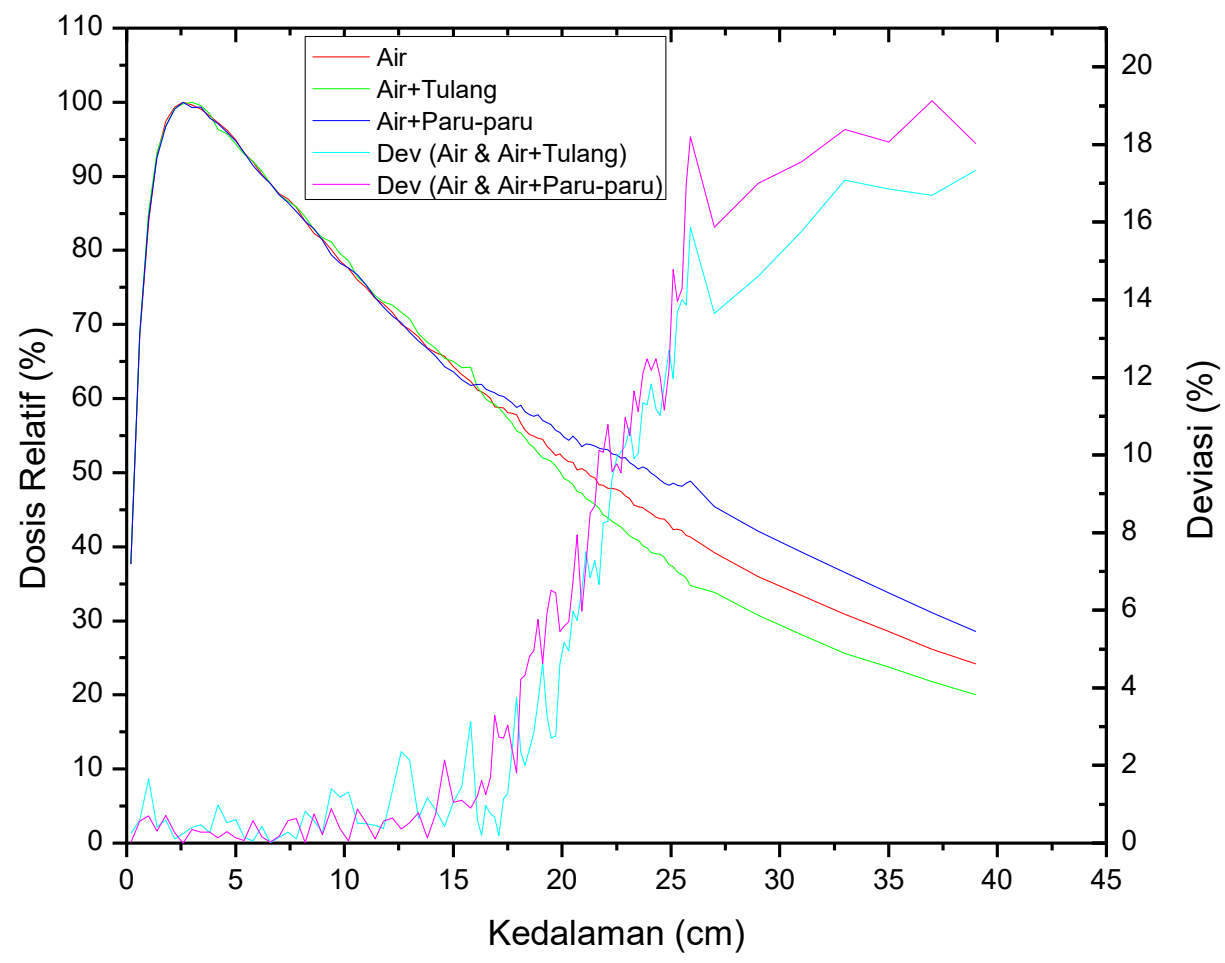

Gambar 6. Perbandingan PDD pada phantom homogen dan phantom non homogen

Berdasarkan gambar 6 terlihat bahwa \% dan 5,90\%. Jaringan paru-paru seperti penyisipan paru-paru dan tulang spons yang berpori, paru-paru akan mengakibatkan adanya perubahan dosis serap mengapung di dalam air karena ada udara di mulai dari daerah permukaan hingga di paru- dalamnya [6]. Hal inilah yang menyebabkan paru dan tulang sampai daerah setelah paru- peningkatan dosis serap pada paru-paru. paru dan tulang itu sendiri. Untuk penyisipan Untuk penyisipan tulang, perbedaan dosis paru-paru, perbedaan dosis serap pada serap pada kedalaman $0 \mathrm{~cm}$ sampai $15 \mathrm{~cm}$ kedalaman $0 \mathrm{~cm}$ sampai $15 \mathrm{~cm}$ mengalami mengalami rata-rata peningkatan sebesar 0,33 rata-rata penuruan sebesar $0,71 \%$, akan tetapi $\%$ dan mengalami rata-rata penurunan pada dosis serap di paru-paru dan daerah setelahnya daerah tulang dan setelahnya sebesar 2,70\% mengalami rata-rata peningkatan sebesar 3,36 dan 5,32\%. 
Tabel 3. Dosis serap dan faktor koreksi untuk medium homogen dan non homogen

\begin{tabular}{|c|c|c|c|c|c|}
\hline \multirow{3}{*}{$\begin{array}{l}\text { Kedalaman } \\
\text { (cm) }\end{array}$} & \multicolumn{3}{|c|}{ Dosis Relatif $(\%)$} & \multicolumn{2}{|c|}{ Faktor Koreksi } \\
\hline & Homogen & Non homogen & Non homogen & Paru-paru & Tulang \\
\hline & Air & Air+paru-par & Air+tulang & & \\
\hline 1 & 83,77174 & 84,35749 & 85,15968 & 1,00011 & 1,01656 \\
\hline 1,4 & 92,83113 & 92,5391 & 93,22297 & 0,99685 & 1,00422 \\
\hline 1,8 & 97,41618 & 96,72619 & 96,83563 & 0,99291 & 0,99404 \\
\hline 3,4 & 99,09406 & 99,3785 & 99,56343 & 1,00287 & 1,00400 \\
\hline 5,4 & 93,17487 & 93,23938 & 93,03545 & 1,00069 & 0,99850 \\
\hline 6,6 & 89,05299 & 89,07563 & 89,06534 & 1,00025 & 1,00013 \\
\hline 7,4 & 86,92068 & 86,41748 & 86,67448 & 0,99421 & 0,99716 \\
\hline 8,6 & 82,28029 & 82,90441 & 82,75418 & 1,00758 & 1,00575 \\
\hline 9,4 & 80,07807 & 79,37092 & 81,19543 & 0,99116 & 1,01395 \\
\hline 10,6 & 76,02319 & 76,68943 & 76,41078 & 1,00876 & 1,00509 \\
\hline 11,4 & 73,56171 & 73,64321 & 73,89979 & 1,00110 & 1,00459 \\
\hline 13,8 & 66,84145 & 66,74837 & 67,62379 & 0,99860 & 1,01170 \\
\hline 15 & 64,30132 & 63,62337 & 64,98389 & 0,98945 & 1,01061 \\
\hline
\end{tabular}

Tabel 3 menunjukan data perubahan dosis serap 4. Simpulan

pada kedalaman $0 \mathrm{~cm}$ sampai $15 \mathrm{~cm}$ dari phantom non homogen, juga menunjukan faktor koreksi untuk kedua phantom non homogen tersebut. Penambahan paru-paru setebal $10 \mathrm{~cm}$ mengakibatkan rentang faktor koreksi 0,97 1,19, sedangkan penambahan tulang setebal 10 cm mengakibatkan rentang faktor koreksi 0,821,03 .
Berdasarkan hasil yang didapat maka dapat disimpulkan bahwa $D_{\max }$ untuk medium homogen jaringan lunak, paru-paru, tulang dan pmma masing-masing adalah 2,7 cm, 9 $\mathrm{cm}, 1,5 \mathrm{~cm}$ dan $2,5 \mathrm{~cm}$. Karakteristik jaringan lunak sama dengan air karena memiliki distribusi dosis serap dan $D_{\max }$ yang sama yaitu 2,7 cm. Pada phantom non homogen, penambahan paru-paru dan tulang ternyata berpengaruh terhadap dosis serap 
pada semua daerah, tidak hanya pada daerah paru-paru dan tulang saja. Penyisipan paruparu setebal $10 \mathrm{~cm}$ mengakibatkan penurunan dosis serap sebesar $0,71 \%$, tetapi menyebabkan peningkatan dosis serap 3,36 $\%$ di daerah paru-paru dan 5,90\% di daerah setelah paru-paru. Penyisipan tulang setebal $10 \mathrm{~cm}$, dosis serap menyebabkan peningkatan $0,33 \%$ di daerah $0 \mathrm{~cm}$ sampai $15 \mathrm{~cm}$ dan penurunan $2,70 \%$ di daerah tulang serta 5,32\% di daerah setelah tulang. Rentang faktor koreksi akibat adanya paruparu yaitu $0,97-1,19$ dan akibat adanya tulang yaitu $0,82-1,03$.

\section{Referensi}

1. Gondhowiardjo, Soeharti. (2004). Penggunaan IPTEK Nuklir dalam pemberian terapi radiasi yang aman dan nyaman. Jakarta: Departemen Radioterapi - RSCM FKUI - Perjan RSCM.

2. Kawrakow, I., Walters. B., D.W.O. Rogers. (2011). BEAMnrc Users Manual. Ottawa: National Research Council of Canada.
3. Ramdani R, Yani S, Rhani MF, Arif I dan Haryanto F. (2015). Commissioing Linear Accelerator Varian Clinax iX Foton Beam 10 MV menggunakan simulasi Monte Carlo EGSnrc Code System. Prosiding Simposium Nasional Inovasi dan Pembelajaran Sains (SNIPS) 2015 ITB Bandung.

4. B. R. B. Walters dan D. W. O. Roger. (2013). DOSXYZnrc User Manuasl Report PIRS-794 . Ottawa: National Research Council of Canada.

5. Rizal, Alfian., Setia Budi, Wahyu., Anam, Choirul. (2012). Simulasi Monte Carlo untuk menentukan dosis sinar-X 6 MV pada ketakhomogenan medium jaringan tubuh. Jurnal Berkala Fisika. Vol.15 No.2 April 2012 hal 49-56.

6. Pearce, C. Evelyn. (2013). Anatomi dan Fisiologi untuk Paramedis. Jakarta: Kompas Gramedia.

7. Anam, Choirul. (2010). Simulasi Monte Carlo untuk kontaminasi elektron pada berkas sinar-X $6 \mathrm{MV}$ produksi pesawat linac Elekta SL15. Depok : FMIPA UI 